\title{
CORRESPONDENCE
}

\section{THE AGE AND TECTONIC RELATIONSHIPS OF EAST AFRICAN VOLCANIC ROCKS}

SIR,-All East African geologists will appreciate Dr. Kent's exposition (Geol. Mag., lxxxi, 1944, 15-27) of the correlation of Tertiary and later volcanic rocks of Kenya and Tanganyika, and their relation to the Rift Faulting. After reading his paper, I should be grateful for the opportunity to submit a few remarks and to add data of interest in connection with Dr. Kent's descriptions and views.

While it is admitted that some of the phonolites overlie Miocene sediments, e.g. in the Kisumu area, does this necessarily apply to all Gregory's Kapitian phonolites, especially those of the type area, the Kapiti Plains, south-east of Nairobi ? One feels that perhaps more convincing evidence is required than similarity of lithological grouping in areas separated by so great a distance.

Dr. Kent remarks on the spread of phonolites in the Kisumu district and suggests they may be somewhat older than the nephelinites of Rusinga. In the northern part of the Uyoma peninsula, however, north-east of Rusinga and between that island and Kisumu, I found in 1937 (Report No. 7, Mining and Geological Department, Kenya, 1938) both nephelinites and phonolites. These overlie sandstones which correspond with Miocene sediments further south in the peninsula, and though nowhere seen in one section, it appears that the phonolite is younger than the nephelinite. I suggest, however, that these areas of different alkaline types may be largely connected with varying subterranean conditions in Miocene times, and that the Uyoma area may be the meeting place of the types derived from the areas at the eastern and western ends of the Kavirondo Gulf, and that there may be little if any difference of age between the two types of lava. This suggestion of different " magmatic basins" is perhaps borne out by Hallam and Edgworth Johnston's discovery in 1935-6, of ijolites and extensive carbonatitic masses in the Home Bay area, east of Rusinga (Report lodged with the Mining and Geological Department, Nairobi, Kenya).

Interesting variations of the phonolites occur north-west of Kisumu between the main northern fault of the Kavirondo Gulf Rift and a companion but post-Miocene fault which bounds the southern edge of the Maragoli granite hills, about 6 miles north of the main fault. In the east, near the Kisumu-Kakamega road they are of Kenya type (cf. Pl. xix, fig. 2, Appendix iii in Gregory's The Rift Valleys and Geology of East Africa, 1921), while a few miles further west apparently contemporaneous lavas are of Losaguta type, as redefined by Campbell Smith (Quart. Journ. Geol. Soc., Ixxxvii, 1931, 236). The two types approach within a mile of each other, but are separated finally by a low granite ridge.

I am not familiar with the sections near Tindaret, but I have had the opportunity of examining a few slides of rocks from that area (Legetet). The nephelinites appear to be of two kinds, older melanocratic augitite types and younger melilite-bearing types. Still more recent lavas (perhaps Pleistocene) appear to be represented by olivine basalt, e.g. at Jeboren Hill. 
The quotation (p. 19) of Sikes's succession around Nairobi is perhaps, through no fault of Dr. Kent's, a little misleading. The Nairobi Claystone should be shown at various horizons between the top of the Nairobi phonolite and the top of the Nairobi trachyte, and it may be questioned whether some of the items between the Kapiti phonolite and the Nairobi trachyte should not be represented as approximately contemporaneous. The succession quoted also omits the pyroclastic facies. These are particularly interesting in the Athi River area where in the pyroclastics between the Kapiti phonolite and the Nairobi phonolite there are intercalations of lacustrine sediments, including green clays, impure diatomite, and gasteropod limestones. The presence of the diatomites may prove of importance in correlation with the extensive diatomite deposits of Lower Pleistocene age in the Rift Valley.

In comments on Mount Elgon (p. 23) Dr. Kent omitted to mention Ödman's valuable work there (Volcanic Rocks of Mount Elgon in British East Africa, Geol. Fören i. Stockholm Förh., lii, 1930, 455-537). Ödman demonstrated the following succession :-

3. Phonolitic stage.-(c) Phonolite.

(b) Phonolitic nepheline basalt.

(a) Phonolitic nephelinite.

2. "Basaltic Stage ",-(c) Melilite nepheline basalt.

(b) Melilite basalt.

(a) Nepheline basalt.

1. Nephelinitic stage.-(a) Nephelinite.

All stages have associated pyroclastic phases, and stages 2 and 3 (a) to $(b)$ have dyke phases. The succession, which Dr. Kent refers to as post Lower Miocene and which Ödman shows to be pre-Pleistocene, does not fit in well with the former's generalized correlation scheme, and as suggested above in connection with another area, leads one to consider that magmatic conditions may have been different in various localities during the Miocene in Kenya.

In considering the extension westwards of the Kavirondo Gulf Rift, Dr. Kent appears to think that the faults terminate about half-way along the Gulf. The Lambwe Valley fault, however, running with a marked scarp from Homa Bay to the area south of Karungu, appears to be the continuation of the southern rift fault. The northern rift fault likewise continues westwards through Asembo as a zone of shearing, but without any marked scarp, and may well bound the Tertiary volcanics of Uyoma, though I was unable to prove this in the field. Hallam and EdgworthJohnston, who found sections in the River Yamariga, showing some of the Lambwe faults to be of normal character, considered that the northern fault of the Lambwe Rift lies buried under the volcanic accumulations of Gwasi. It seems more probable, however, that the line of fracture passes west from Uyoma out into Lake Victoria and to the north of Rusinga Island.

In conclusion I would like to congratulate Dr. Kent on bringing forward further evidence in support of the hypothesis of a compressional origin for the Kenya Rifts.

William Pulfrey.

NAIROBI, KeNYA. 18th May, 1944. 